\title{
Effect of Gradient Decompression on the Occurrence of Intraoperative Hypotension and Prognosis in Traumatic Brain Injury
}

\author{
Gradiyent Dekompresyonun Travmatik Beyin Hasarnda Intraoperatif \\ Hipotansiyon Oluşması ve Prognoza Etkisi
}

\author{
Xu MIN ${ }^{1}$, Wang CUN-ZU², Wang YUN-HUAN ${ }^{3}$, Lu XIAO-FENG ${ }^{1}$, Bao QING ${ }^{1}$, Xie ZHENG-XING ${ }^{4}$, \\ Zhuang YAN ${ }^{4}$, Chang ZHI-YING ${ }^{5}$, Wu MIN ${ }^{4}$, Chen ZE-JUN ${ }^{4}$ \\ ${ }^{1}$ Jiangsu University, Clinical Medicine College, Zhenjiang Jiangsu, China \\ ${ }^{2}$ Yangzhou Jiangsu, Wound Institute of Jiangsu University, Northern Jiangsu People's Hospital, Department of Neurosurgery, Zhenjiang Jiangsu, \\ China \\ 3Jintan TCM Hospital, Department of Anesthesiology, Changzhou Jiangsu, China \\ ${ }_{4}^{4}$ The Affiliated Hospital of Jiangsu University, Department of Neurosurgery, Zhenjiang Jiangsu, China \\ ${ }^{5}$ The Affiliated Hospital of Jiangsu University, Department of Medical Record Library, Zhenjiang Jiangsu, China
}

Corresponding Author: Wang CUN-ZU / E-mail: wangcunzu@ujs.edu.cn

\begin{abstract}
AIM: To investigate the effect of gradient decompression on the occurrence of intraoperative hypotension and prognosis in traumatic brain injury.

MATERIAL and METHODS: A retrospective analysis was performed in 186 hospitalized patients from January, 2008 to January, 2012 in the Affiliated Hospital of Jiangsu University. Demographic data, the abnormality of pupils, and Glasgow Coma Scale (GCS) before operation, and gradient decompression measures, and intraoperative hypotension during operation, and mortality after operation were recorded. Gradient decompression measures were mannitol, hyperventilation, graded craniotomy, and Chi-square test was conducted to evaluate the association of gradient decompression with intraoperative hypotension and prognosis.

RESULTS: All the gradient decompression measures were shown non-significantly associated with the occurrence of intraoperative hypotension and prognosis, including mannitol $(p=0.852, p=0.328)$, hyperventilation $(p=0.484, p=0.619)$ and graded craniotomy $(p=0.326$, $p=0.605)$. Mannitol with hyperventilation $(p=0.733, p=0.758)$, mannitol with graded craniotomy $(p=0.319, p=1.000)$, hyperventilation with graded craniotomy $(p=0.269, p=0.685)$ and all the three measures $(p=0.135, p=0.589)$ were also non-significantly associated with the occurrence of intraoperative hypotension and prognosis. The abnormality of pupils $(p=0.006), G C S(p<0.001)$ and hypotension $(p=0.006)$ were closely associated with the prognosis.
\end{abstract}

CONCLUSION: Gradient decompression is not effective in avoiding the occurrence of intraoperative hypotension and improving the prognosis. It provides a new insight into clinical measures for curing patients with severe traumatic brain injury (sTBI).

KEYWORDS: Traumatic brain injury, Gradient decompression, İntraoperative hypotension, Prognosis

öz

AMAÇ: Gradiyent dekompresyonun travmatik beyin hasarında intraoperatif hipotansiyon oluşması ve prognozunda etkisini incelemek.

YÖNTEM ve GEREÇLER: Jiangsu Üniversitesi Hastanesinde Ocak 2008 ile Ocak 2012 arasında yatan 186 hastada retrospektif bir analiz yapıldı. Ameliyattan önce demografik veriler, pupil anormalliği, Glasgow Koma Skoru (GKS) ve gradiyent dekompresyon önlemleri, ameliyat sırasında intraoperatif hipotansiyon ve ameliyattan sonra mortalite kaydedildi. Gradiyent dekompresyon önlemleri olarak mannitol, hiperventilasyon, ve dereceli kranyotomi kullanıldı ve gradiyent dekompresyonun intraoperatif hipotansiyon ve prognozla ilişkisini değerlendirmek için Ki-kare testi kullanıldı.

BULGULAR: Mannitol ( $p=0,852, p=0,328)$, hiperventilasyon $(p=0,484, p=0,619)$ ve dereceli kranyotomi $(p=0,326$, $p=0,605)$ dahil olmak üzere tüm gradiyent dekompresyon önlemlerinin intraoperatif hipotansiyon oluşması ve prognozla önemli olmayan bir şekilde ilişkili olduğu gösterildi. Mannitol ve hiperventilasyon ( $p=0,733, p=0,758)$, mannitol ve dereceli kranyotomi $(p=0,319, p=1.000)$, hiperventilasyon ve dereceli kranyotomi $(p=0,269, p=0,685)$ ve üçönlemin tümü $(p=0,135, p=0,589)$ yine intraoperatif hipotansiyon oluşması ve prognozla önemli olmayan şekilde ilişkiliydi. Pupillerin anormalliği $(p=0,006)$, GKÖ $(p<0,001)$ ve hipotansiyon $(p=0,006)$ prognozla yakından ilişkiliydi.

SONUÇ: Gradiyent dekompresyon, intraoperatif hipotansiyon oluşmasından kaçınmak ve prognozu daha iyi hale getirmekte etkin değildir. Şiddetli travmatik beyin hasarı olan hastaların tedavisi açısından klinik önlemlere yeni bir bakış sağlanmıştır.

ANAHTAR SÖZCÜKLER: Travmatik beyin hasarı, Gradiyent dekompresyon, İntraoperatif hipotansiyon, Prognoz 


\section{INTRODUCTION}

Craniocerebral trauma is a common neurosurgical disease. The incidence of craniocerebral trauma in China is more than 100 per 10 million, approaching to the level of western developed countries (150-200 per 10 million) (26). Hypotension is an independent predictor of poor prognosis in traumatic brain injury (TBI) patients, and intraoperative hypotension (IHT) is one of the special aspects. Patients with craniocerebral trauma may have mass lesions or develop cerebral edema, which can lead to increased intracranial pressure ICP (7). A variety of measures have been used in the clinical treatment of elevated ICP. Osmotic agents, such as mannitol, are a key component in the medical management of elevated ICP (18). The difference of mannitol between IHT and non-IHT remains inconsistent $(17,19)$. Hyperventilation is also a theoretical advantage to control ICP by causing vasoconstriction and the subsequent decrease in cerebral blood flow (11). However, there is still controversy over whether or not patients should be hyperventilated after traumatic brain injury (12).

In addition, decompression craniotomy, which provides gradual decompression, and decreases intracranial pressure and the length of stay in the intensive care unit (ICU) can be used $(4,16,21)$. Intracranial pressure volume-pressure curve illustrates that when the ICP is decompensated, a small increase in the cranial contents can cause a sharp rise of ICP. On the contrary, a small reduction in the cranial contents may cause significantly decline of intracranial pressure. Under the high intracranial pressure state, a small incision and graded decompression can gradually reduce the compliance of brain tissue in the bone window. It can reduce the partial pressure gradient and enable the ICP to decline rapidly but in a gradual process. The effect of surgical decompression on mortality and overall functional outcome remains controversial.

Traumatic intracranial hemorrhage (TICH), such as cerebral contusion, subdural hematoma and epidural hematoma may cause catastrophic IHT during decompression surgery for $\operatorname{TICH}(8,15)$. Although hypotension in patients has been studied in a variety of settings, including the pre-hospital phase, emergency department, and intensive care units $(1,6,26)$, intraoperative data on hypotension are scarce. In this study, we focused on the three measures above to further investigate the effect of gradient decompression on the occurrence of intraoperative hypotension and prognosis.

\section{PATIENTS and METHODS}

\section{Patients Collection}

In the present study, we collected 186 sTBI patients $(\mathrm{GCS}<9)$ from January, 2008 to January, 2012 in the Affiliated Hospital of Jiangsu University. Patients' gender, age, pupils' abnormality, GCS and the application of mannitol, hyperventilation or graded craniotomy were recorded before surgery. GCS including eye opening, verbal response and motor response ranged from 3 to 8 points. We took one-month mortality after surgery as a prognostic indicator.

\section{Gradient Decompression Methods}

Mannitol, hyperventilation and graded craniotomy were three common measures in our clinical work. We first used mannitol, hyperventilation or graded craniotomy as our gradient decompression measure. Then, we combined them two at a time and then all three. Through this method, we evaluated gradient decompression measures according to the occurrence of intraoperative hypotension and prognosis in TBI.

\section{Statistical Analysis}

All the variables were coded as qualitative and analyzed with the SPSS17.0 statistical package. A descriptive analysis was performed on the entire patient sample. The $X^{2}$ test (with Yates correction when indicated) and the Fisher exact test were used to compare categorical qualitative variables. Data are expressed as mean \pm standard deviation (S.D.) and a $p$-value of less than 0.05 was considered significant.

\section{RESULTS}

\section{Patients}

Nine cases with systolic blood pressure $<90 \mathrm{mmHg}$ and two patients aged $<18$ years of age were excluded. The mean age of the remaining 175 patients was $49.16 \pm 15.24$ years with 136 males; 97 had cerebral contusion; 2 diffuse axonal injury and brain stem injury; 123 subdural hematoma; and 51 epidural hematoma. Preoperative GCS ranged between 3 and 5 in 88 patients and 6 and 8 in 87 patients. Fifty-two patients had bilateral normal pupils, 77 patients had bilateral anisocoria, 35 had bilateral mydriasis, 5 patients had bilateral miosis and the the pupils could not be observed in the other 6 patients. Forty-one patients $(23.2 \%)$ were dead within a month after surgery, and 134 patients lived more than one month. In the survivors, Glasgow outcome scale (GOS) ranged from 1 to 3 in 43 patients and from 4 to 5 in 90 patients.

\section{Gradient Decompression and the Occurrence of IHT}

Intraoperative hypotension (systolic blood pressure $<90$ $\mathrm{mmHg}$ (7) occurred during decompression by dural opening. Due to anesthesia-induced hypotension, twenty-two patients were excluded. Based on systolic arterial blood pressure, 175 patients were divided into two groups: patients with $\mathrm{IHT}(\mathrm{IHT}$ group: $n=43$ ) and patients without IHT (non-IHT group: $n=$ 110).

All the studied measures were shown to be non-significantly associated with the occurrence of intraoperative hypotension, including mannitol $(p=0.852)$, hyperventilation $(p=0.484)$ and graded craniotomy $(p=0.326)$. Each two or all three measures were also non-significantly associated with the occurrence of intraoperative hypotension. Besides, there was no group difference in gender, age and abnormality of the pupils. However, there was a significant group difference in the GCS score $(\mathrm{p}=0.032$ ) (Table I).

\section{Gradient Decompression and Prognosis}

All the gradient decompression measures were shown to 
be non-significantly associated with prognosis, including mannitol $(p=0.328)$, hyperventilation $(p=0.619)$ and graded craniotomy $(p=0.605)$. Each two or all three measures were also non-significantly associated with prognosis. Besides, there was no group difference in gender and age. There was a significant group difference in the abnormality of the pupils $(p=0.006)$ and GCS score $(p<0.001)$. Moreover, the occurrence of intraoperative hypotension was significantly associated with the prognosis $(\mathrm{p}=0.001)$ (Table II).

\section{DISCUSSION}

Patients with TBI may have increased ICP (7). When high ICP is suddenly reduced after craniotomy and decompression, the increased sympathetic tone may suddenly decrease, dominating systemic vascular resistance with returned parasympathetic nerve and producing neurogenic hypotension (22). Though a variety of measures have been used in clinical treatment of elevated ICP (22) there is still no agreement on using them.
The three main components in the medical management of elevated ICP, i.e. osmotic agents such as mannitol, hyperventilation, and decompression craniotomy constitute the vital strategies in our clinical work. As determined by the intracranial volume-pressure curve, using gradient decompression with each one, each two or all three measures above, may reduce ICP rapidly but in a gradual and reasonable process. Hypotension is an independent and important predictor of prognosis in trauma patients (10). Our retrospective study demonstrated that all the gradient decompression measures including mannitol, hyperventilation and decompression craniotomy were not significantly associated with the occurrence of IHT (Table I), as partially consistent with Deepak Sharma's study (8). This study failed to obtain evidence of ICP monitoring during the craniotomy or drug treatment process. It becomes difficult to identify the effect of gradient decompression on ICP in our study. In this study, gradient decompression measures were

Table I: Group Difference of Clinical Parameters in Non-IHT and IHT Patients

\begin{tabular}{|l|c|c|c|}
\hline & Non-IHT $(\mathbf{n = 1 1 0})$ & IHT $(\mathbf{n = 4 3})$ & P-value \\
\hline Gender (male:female) & $88: 22$ & $32: 11$ & 0.513 \\
\hline Age (range) & $51.95 \pm 16.41$ & $46.89 \pm 14.75$ & 0.282 \\
\hline Pupil abnormality (yes:no) & $73: 37$ & $32: 11$ & 0.557 \\
\hline GCS (3-5: 6-8) & $42: 68$ & $32: 11$ & 0.032 \\
\hline A: Mannitol infusion (yes:no) & $43: 67$ & $17: 26$ & 0.852 \\
\hline B: Hyperventilation (yes:no) & $18: 92$ & $9: 34$ & 0.484 \\
\hline C: Graded craniotomy (yes:no) & $16: 94$ & $9: 34$ & 0.326 \\
\hline A+B (yes:no) & $9: 101$ & $4: 39$ & 0.733 \\
\hline A+C (yes:no) & $7: 103$ & $5: 38$ & 0.319 \\
\hline B+C (yes:no) & $5: 105$ & $4: 39$ & 0.269 \\
\hline A+B+C (yes:no) & $2: 108$ & $3: 40$ & 0.135 \\
\hline Prognosis (dead:survival) & $17: 93$ & $18: 25$ & 0.001 \\
\hline
\end{tabular}

Table II: Single-Factor Analysis of the Prognosis of 153 Patients

\begin{tabular}{|c|c|c|c|}
\hline & $\operatorname{Dead}(n=35)$ & Survival( $(n=118)$ & P-value \\
\hline Gender (male:female) & 29:6 & $91: 27$ & 0.640 \\
\hline Age (range) & $53.57 \pm 12.77$ & $46.75 \pm 15.75$ & 0.153 \\
\hline Pupil abnormality (yes:no) & $31: 4$ & 74:44 & 0.006 \\
\hline GCS $(3-5: 6-8)$ & $28: 7$ & $46: 72$ & $<0.001$ \\
\hline A: Mannitol infusion (yes:no) & $16: 19$ & $44: 74$ & 0.328 \\
\hline B: Hyperventilation (yes:no) & $7: 28$ & $20: 98$ & 0.619 \\
\hline C: Graded craniotomy (yes:no) & $7: 29$ & 18:99 & 0.605 \\
\hline$A+B$ (yes:no) & $2: 33$ & $11: 107$ & 0.758 \\
\hline$A+C$ (yes:no) & $3: 32$ & 9:109 & 1.000 \\
\hline$B+C$ (yes:no) & $1: 34$ & $8: 110$ & 0.685 \\
\hline$A+B+C$ (yes:no) & $0: 35$ & $5: 113$ & 0.589 \\
\hline Hypotension (Non-IHT :IHT) & $17: 18$ & $93: 25$ & 0.001 \\
\hline
\end{tabular}


not effective on the occurrence of IHT and the prognosis. Further investigations are required to establish the effect of gradient decompression measures.

Meanwhile, there has been much work on the prognosis. Demographic factors such as age $(13,23)$, sex $(3,13,24)$, clinical severity $(9,14)$ etc. are considered to be associated with therapy outcome or prognosis. As was shown in this study, the mortality or prognosis was significantly associated with the abnormality of the pupils $(p=0.006), G C S$ score $(p<0.001)$ and IHT $(p=0.001)$, very similar to the previous studies $(5,10,15,19,26)$. Due to this close relationship, the gradient decompression measures were also not significantly associated with the prognosis (Table II). That means gradient decompression is not an effective measure to decrease the occurrence of $\mathrm{IHT}$ and improve the prognosis.

In addition, this study has several limitations. The most important limitation is the retrospective study design and the reliance on medical records. We are unable to precisely report the duration or timing of hypotension and conducted ICP monitoring. Despite these limitations, this study provides new insights into the gradient decompression measures and suggests a new perspective for future considerations of the role of this therapy strategy in IHT patients.

\section{REFERENCES}

1. Chesnut RM, Ghajar J, et al: Brain trauma foundation. American Association of Neurological Surgeons; Congress of Neurological Surgeons; The joint section on neurotrauma and critical care. AANS/CNS; Bratton SL, Guidelines for the management of severe traumatic brain injury. I. Blood pressure and oxygenation. J Neurotrauma 24 (suppl 1): S7-S13, 2007

2. Chesnut RM, Marshall LF, Klauber MR, Blunt BA, Baldwin N, Eisenberg HM, Jane JA, Marmarou A, Foulkes MA: The role of secondary brain injury in determining outcome from severe head injury. J Trauma 34: 216-222, 1993

3. Colantonio A, Escobar MD, Chipman M, McLellan B, Austin PC, Mirabella G, Ratcliff G; Predictors of postacute mortality following traumatic brain injury in a seriously injured population. J Trauma 64: 876-882, 2008

4. Cooper DJ, Rosenfeld JV, Murray L, Arabi YM, Davies AR, D'Urso P, Kossmann T, Ponsford J, Seppelt I, Reilly P, Wolfe R: Decompressive craniectomy in diffuse traumatic brain injury. N Engl J Med 364: 1493-1502, 2011

5. Franschman G, Peerdeman SM, Andriessen TM, Greuters $S$, Toor AE, Vos PE, Bakker FC, Loer SA, Boer C: Effect of secondary prehospital risk factors on outcome in severe traumatic brain injury in the context of fast access to trauma care. J Trauma 71: 826-832, 2011

6. Jeremitsky E, Omert L, Dunham CM, Protetch J, Rodriguez A: Harbingers of poor outcome the day after severe brain injury: Hypothermia, hypoxia, and hypoperfusion. J Trauma 54: 312-319, 2003
7. Katayama Y, Tsubokawa T, Miyazaki S, Kawamata T, Yoshino A: Oedema fluid formation within contused brain tissue as a cause of medically uncontrollable elevation of intracranial pressure: The role of surgical therapy. Acta Neurochir Suppl (Wien) 51: 308-310, 1990

8. Kinoshita K, Kushi H, Sakurai A, Utagawa A, Saito T, Moriya $\mathrm{T}$, Hayashi N: Risk factors for intraoperative hypotension in traumatic intracranial hematoma. Resuscitation 60:151-155, 2004

9. Lefering R, Paffrath T, Linker R, Bouillon B, Neugebauer EA: Head injury and outcome--what influence do concomitant injuries have? J Trauma 65: 1036-1044, 2008

10. Lipsky $A M$, Gausche-Hill M, Henneman PL, Loffredo AJ, Eckhardt PB, Cryer HG, de Virgilio C, Klein SL, Bongard FS, Lewis RJ: Prehospital hypotension is a predictor of the need for an emergent, therapeutic operation in trauma patients with normal systolic blood pressure in the emergency department. J Trauma 61: 1228-1233, 2006

11. Moszynski K, Lewelt W: Hyperventilation in neurosurgery. Anaesth Resusc Intensive Ther 3: 135-140, 1975

12. Muizelaar JP, Marmarou A, Ward JD, Kontos HA, Choi SC, Becker DP, Gruemer H, Young HF: Adverse effects of prolonged hyperventilation in patients with severe head injury: A randomized clinical trial. J Neurosurg 75: 731-739, 1991

13. Perel $P$, Arango $M$, Clayton $T$, Edwards $P$, Komolafe E, Poccock S, Roberts I, Shakur H, Steyerberg E, Yutthakasemsunt S: Predicting outcome after traumatic brain injury: Practical prognostic models based on large cohort of international patients. BMJ 336: 425-429, 2008

14. Perel P, Edwards P, Wentz R, Roberts I: Systematic review of prognostic models in traumatic brain injury. BMC Med Inform Decis Mak 6:38, 2006

15. Pietropaoli JA, Rogers FB, Shackford SR, Wald SL, Schmoker JD, Zhuang J: The deleterious effects of intraoperative hypotension on outcome in patients with severe head injuries. J Trauma 33: 403-407, 1992

16. Plesnila N: Decompression craniectomy after traumatic brain injury: Recent experimental results. Prog Brain Res 161: 393-400, 2007

17. Sakowitz OW, Stover JF, Sarrafzadeh AS, Unterberg AW, Kiening KL: Effects of mannitol bolus administration on intracranial pressure, cerebral extracellular metabolites, and tissue oxygenation in severely head-injured patients. J Trauma 62: 292-298, 2007

18. Scalfani MT, Dhar R, Zazulia AR, Videen TO, Diringer MN: Effect of osmotic agents on regional cerebral blood flow in traumatic brain injury. J Crit Care 27: 526-527, 2012

19. Sharma D, Brown MJ, Curry P, Noda S, Chesnut RM, Vavilala MS: Prevalence and risk factors for intraoperative hypotension during craniotomy for (traumatic brain injury. J Neurosurg Anesthesiol 24: 178-184, 2012

20. Sharma D, Jelacic J, Chennuri R, Chaiwat O, Chandler W, Vavilala MS: Incidence and risk factors for perioperative hyperglycemia in children with traumatic brain injury. Anesth Analg 108: 81-89, 2009 
21. Shen J, Pan JW, Fan ZX, Zhou YQ, Chen Z, Zhan RY: Surgery for contralateral acute epidural hematoma following acute subdural hematoma evacuation: Five new cases and a short literature review. Acta Neurochir (Wien) 155: 335-341, 2013

22. The Brain Trauma Foundation, The American Association of Neurological Surgeons, The Joint Section on Neurotrauma and Critical Care: Computed tomography scan features. J Neurotrauma 17: 597-627, 2000

23. Tokutomi T, Miyagi T, Ogawa T, Ono J, Kawamata T, Sakamoto T, Shigemori M, Nakamura N: Age-associated increases in poor outcomes after traumatic brain injury: A report (from the Japan Neurotrauma Data Bank. J Neurotrauma 25: 14071414,2008
24. Utomo WK, Gabbe BJ, Simpson PM, Cameron PA: Predictors of in-hospital mortality and 6-month functional outcomes in older adults after moderate to severe traumatic brain injury. Injury 40: 973-977, 2009

25. Wang ZC, Zhao YL, Craniocerebral trauma clinical research and standardized treatment. Chin J Neurosurg 17:133-134, 2001

26. Zafar SN, Millham FH, Chang Y, Fikry K, Alam HB, King DR, Velmahos GC, de Moya MA: Presenting blood pressure in traumatic brain injury: A bimodal distribution of death. J Trauma 71: 1179-1184, 2011 